\title{
Combined treatment of nightmares with targeted memory reactivation and imagery rehearsal therapy: a randomized controlled trial
}

\author{
Sophie Schwartz ${ }^{1,2}$, Alice Clerget $^{1}{ }^{\text {, Lampros Perogamvros }}{ }^{1,2,3,4}$ \\ ${ }^{1}$ Department of Basic Neurosciences, Faculty of Medicine, University of Geneva, Geneva, \\ Switzerland
}

${ }^{2}$ Swiss Center for Affective Sciences, University of Geneva, Geneva, Switzerland.

${ }^{3}$ Center for Sleep Medicine, Geneva University Hospitals, Geneva, Switzerland

${ }^{4}$ Department of Psychiatry, Geneva University Hospitals, Geneva, Switzerland.

Corresponding Author: Lampros Perogamvros MD, Chemin du Petit-Bel-Air 2, 1225 ChêneBourg, tel : +4122795532901, lampros.perogamvros@hcuge.ch

Running title: Treating nightmares with targeted memory reactivation

Keywords: sleep, REM sleep, dreaming, nightmares, targeted memory reactivation, imagery rehearsal therapy 
medRxiv preprint doi: https://doi.org/10.1101/2022.02.17.22270256; this version posted February 19, 2022. The copyright holder for this preprint (which was not certified by peer review) is the author/funder, who has granted medRxiv a license to display the preprint in All rights reserved. No reuse allowed without permission.

\section{Abstract}

Background: Nightmare disorder (ND) is characterized by dreams with strong negative emotions occurring during rapid-eye movement (REM) sleep. ND is mainly treated by imagery rehearsal therapy (IRT), where the patients are asked to change the negative story line of their nightmare to a more positive one.

Methods: We used targeted memory reactivation (TMR) during REM sleep to strengthen IRTrelated memories and accelerate remission of ND. Thirty-six patients (27 women) with ND were asked to perform an initial IRT session and, while they generated a positive outcome of their recurrent nightmare, half of the patients were exposed to a sound (TMR group), while no such pairing with a sound took place for the other half (control group). During the next two weeks, all patients performed IRT every evening at home, and were exposed to the sound during REM sleep with a wireless headband, which automatically detected sleep stages. The frequency of nightmares per week at 2 weeks and at a three-month follow-up was used as primary outcome measure.

Results: We found that the patients of the TMR group had less frequent nightmares $(p=.026$, Cohen's $d=1.05$ ) and more positive dream emotions ( $p=.004$, Cohen's $d=1.06$ ) than patients of the control group after two weeks of IRT, and a sustained decrease of nightmares after 3 months $(p=.006$, Cohen's $d=1.45)$.

Conclusions: By demonstrating the effectiveness of TMR during sleep to potentiate therapy, these results have clinical implications for the management of ND, with plausible relevance for learning-based therapies in other psychiatric diseases. Additionally, these findings show that TMR applied during REM sleep can modulate emotions in dreams.

Clinical trial registration: ClinicalTrials.gov identifier NCT05237778 
medRxiv preprint doi: https://doi.org/10.1101/2022.02.17.22270256; this version posted February 19, 2022. The copyright holder for this preprint (which was not certified by peer review) is the author/funder, who has granted medRxiv a license to display the preprint in All rights reserved. No reuse allowed without permission.

\section{Introduction}

Nightmares are characterized by the experience of strong negative emotions occurring usually during REM sleep. They involve images and thoughts of aggression, interpersonal conflict, and failure, and emotions like fear, anger and sadness (1). Nightmares may be idiopathic (without clinical signs of psychopathology) or associated with other disorders including post-traumatic stress disorder (PTSD). Posttraumatic nightmares are usually recurrent replications of the traumatic event, while idiopathic nightmares can have a variety of content. Independently of their underlying origin, when nightmares are frequent and cause significant distress or impairment in social, occupational, or other important areas of functioning, they characterize the so-called nightmare disorder (ND), according to the international classifications of mental and sleep disorders (DSM-5, ICSD-3) $(2,3)$. The prevalence of ND at a clinically significant frequency ( $>1$ episode per week) is $\sim 4 \%$ of the general adult population $(4,5)$.

The pathophysiology and neural correlates of nightmares remain largely unknown. It has been proposed that ND involves a dysfunction of fear extinction (6), but solid empirical support for this hypothesis is still lacking. As a reminder, fear extinction is defined as the gradual decrease of a conditioned response (e.g. avoidance), when a conditioned stimulus (CS) is presented without reinforcement from an unconditioned aversive stimulus (US) (7). During fear extinction, an inhibitory non-fearful (safety) memory that opposes the expression of the original fear memory is formed (8). Fear extinction is supported by a network that encompasses limbic regions (e.g. amygdala, medial prefrontal cortex, hippocampus, anterior cingulate cortex, insula), with the medial prefrontal cortex (mPFC) exerting an important inhibitory control on the amygdala $(9,10)$. In the context of dreaming, it has been proposed 
medRxiv preprint doi: https://doi.org/10.1101/2022.02.17.22270256; this version posted February 19, 2022. The copyright holder for this preprint (which was not certified by peer review) is the author/funder, who has granted medRxiv a license to display the preprint in All rights reserved. No reuse allowed without permission.

that normal dreaming promotes fear extinction, by associating previous fearful memories (CS) with novel and dissociated contexts (in the dream itself) that do not predict the US (6).

When untreated, ND can persist for decades (11). The only treatment with level A recommendation (recommended) for ND is the Imagery Rehearsal Therapy (IRT) (12). IRT is a cognitive-behavioral technique that encompasses the following steps: recalling the nightmare, changing the negative story line, towards a more positive ending, and rehearsing the rewritten dream scenario during the day, which ultimately helps to reduce nightmares during sleep (13). This technique can be learned in one session (14-16), and practiced for 5-10 minutes per day while awake. A partial remission of nightmare frequency and severity has been observed after regular use of the technique for two weeks (13). Although IRT appears to be effective in the management of nightmares, approximately $30 \%$ of patients are unresponsive to this treatment (13). Therefore, new options to accelerate and enhance therapeutic outcome are needed.

Emerging evidence shows that REM sleep plays a causal role in extinction and emotion regulation. Several studies have demonstrated how REM sleep favors the successful consolidation of extinction memory (17-21). Other studies also showed that REM sleep helps to decrease the experienced affective tonus, thus leading to higher familiarity with emotionally negative stimuli (emotional depotentiation) (22-24) and to the consolidation of positive emotional memories $(25,26)$. Developing experimental strategies aiming at further potentiating this role of REM sleep could offer new therapeutic avenues for disorders with deficient emotion regulation (e.g., mood disorders, anxiety disorders, nightmares). 
medRxiv preprint doi: https://doi.org/10.1101/2022.02.17.22270256; this version posted February 19, 2022. The copyright holder for this preprint (which was not certified by peer review) is the author/funder, who has granted medRxiv a license to display the preprint in All rights reserved. No reuse allowed without permission.

Targeted memory reactivation (TMR) is a technique used to modify memory formation through the application of cues during sleep (27). In a classic TMR protocol, a sensory (e.g. olfactory, auditory) cue is associated with a learning procedure during the day, and then administered during sleep. In that way, the replay of the associated memory and its corresponding neural representation in memory networks are artificially promoted, a procedure which will usually strengthens memory consolidation (27). TMR can improve declarative and procedural memory consolidation in humans $(28,29)$, with the combined effect of sleep with TMR adding up to a memory enhancement of $35 \%$ as compared to wakefulness (30). While the beneficial effects of TMR in NREM for memory consolidation is undeniable (31), less is known about applying TMR in REM sleep. Some studies suggested that TMR in REM sleep enhanced memory $(32,33)$, including the strengthening of associative emotional memory (34) and the reduction of negative valence of recently encountered stimuli $(35,36)$. Importantly, sleep alone may not guarantee these emotional modulations; targeted potentiation of post-learning REM sleep seems necessary for this effect to be observed (37).

The current study included 36 adults with ND and tested whether a TMR manipulation added to an IRT protocol accelerated remission of ND. More specifically, we investigated whether presenting, during REM sleep, a sound previously associated with a positive scenario of a nightmare (generated during an IRT session) decreased nightmare frequency (more than IRT alone). Clinical evaluation of the severity of nightmares before and after this intervention took place using the validated Nightmare Frequency Questionnaire (NFQ, primary outcome measure) (38), which retrospectively identifies the frequency of nightmares. Specifically, we hypothesized that ND patients treated with IRT and who were exposed, during REM sleep and over 14 nights, to a sound that had previously been associated with the new positive dream 
medRxiv preprint doi: https://doi.org/10.1101/2022.02.17.22270256; this version posted February 19, 2022. The copyright holder for this preprint (which was not certified by peer review) is the author/funder, who has granted medRxiv a license to display the preprint in

All rights reserved. No reuse allowed without permission.

scenario of IRT (TMR group), will have more reduced frequency of nightmares compared to participants with stimulation of the same, but non-associated, sound during REM sleep (control group). In the current TMR protocol, we associated a sound with a positive dream scenario, and therefore formulated an additional, secondary hypothesis according to which positive emotions should be reported more frequently after IRT in the dreams from the TMR group compared to the control group.

\section{Methods and Materials}

\section{Participants}

Thirty-six individuals ( 27 women and 9 men) aged from 20 to 35 years old $(M=26, S D=4.22$ ) were included. Participants were recruited at the Center for Sleep Medicine, University Hospitals of Geneva. Diagnosis of ND was done by a sleep specialist according to the International Classification of Sleep Disorders (ICSD-3) diagnostic and coding manual (3). Patients with ND and with at least moderate severity ( $>1$ episode per week) were included. All patients reported significant distress or impairment in social, occupational, or other important areas of functioning because of their nightmares, mainly fatigue, mood disturbance (i.e., persistence of nightmare affect) and cognitive impairments (i.e., intrusive nightmare imagery). All patients had idiopathic nightmares, as they reported that their nightmares were unrelated to a traumatic life event. A neuropsychiatric evaluation was performed to exclude patients with comorbidities, such as severe depression (measured by Beck Depression Inventory/ BDIII (39), insomnia (Pittsburgh Sleep Quality Index (PSQI) (40), psychosis or anxiety disorder. We also excluded any patient with symptoms of obstructive sleep apnea syndrome, restless legs syndrome, neurological disease or using medications that would be likely to produce 
medRxiv preprint doi: https://doi.org/10.1101/2022.02.17.22270256; this version posted February 19, 2022. The copyright holder for this preprint (which was not certified by peer review) is the author/funder, who has granted medRxiv a license to display the preprint in All rights reserved. No reuse allowed without permission.

nightmares (e.g. hypnotics, $\beta$-blockers, amphetamines, antimicrobial agents). Patients with anxiolytics, antipsychotic or antidepressant medication were excluded. Signed informed consent was obtained from all participants before the experiment, and ethical approval for the study was obtained from the ethical committee of the canton of Geneva, Switzerland ('Commission Cantonale d'Ethique de la Recherche sur l'être humain').

\section{Procedure}

The experimental design of this study is presented in Figure 1, and corresponds to a singleblind, randomized controlled design, with random assignment of ND patients to either the TMR group or control group. A power analysis based on effect sizes observed in Simon et al. (41) indicated that for a Cohen's $d \geq 1$ on the primary outcome measure, a sample size of 18 participants per arm would result in a power of $80 \%$ for an $\alpha=.05$. All sessions took place at the Center for Sleep Medicine, University Hospitals of Geneva. After an initial assessment and diagnosis of ND (T1, Visit 1), all participants filled in a dream diary and a sleep diary, and wore an actigraph for two weeks. At the end of this period, all patients came to the center for a single, individual session of IRT (Visit 2). At the end of this session, participants of the TMR group received a sound (duration $1 \mathrm{sec}$, presented every $10 \mathrm{sec}$ ) while imagining the new positive dream scenario generated during IRT for 5 minutes. Participants from the control group also performed the 5-min imagery of the new positive dream scenario, but without sound presentation. Participants then returned home. During the following two weeks, all patients received the sound during their REM sleep. The application of sounds took place with a wearable headband device that delivered the stimulation during REM sleep (see 'Sleep assessment'). The patients also filled in a sleep and dream diary during these two weeks. At 
medRxiv preprint doi: https://doi.org/10.1101/2022.02.17.22270256; this version posted February 19, 2022. The copyright holder for this preprint (which was not certified by peer review) is the author/funder, who has granted medRxiv a license to display the preprint in All rights reserved. No reuse allowed without permission.

the end of this period, they came back to the lab for a new session during which their ND was assessed (T2, Visit 3). Finally, a third assessment session took place 3 months later (3-month follow-up) (T3, Visit 4), without any intervention between Visit 3 and 4. Twenty-eight patients (i.e., 14 subjects in each group out of the 36 participants) responded to this third assessment (dropout rate $=22 \%$ ).

-Please insert Figure 1 here-

\section{Imagery Rehearsal Therapy (IRT)}

A single IRT session is sufficient for the patient to learn the IRT techniques (16). As the main objective of the study was to assess the impact of TMR on nightmare severity, a single treatment session focusing only on nightmares (and not on psychoeducation included in the more classic 4-session IRT (13)) was selected to avoid potential confounding effects of psychoeducation on treatment effect. Specifically, as in (16), information about nightmares was given to the patients and then IRT was introduced and practiced. The patients were first instructed to choose their most frequent nightmare, and to write it down. They were then asked to change their initial nightmare in any way they wish, so that the new version would be neither unpleasant nor distressing. Then, a 5-min period was given for imagery rehearsal of the new dream. Patients were then instructed to practice imagery of the new dream scenario at home for 5 minutes per day, at least once a day, every day, during the following two weeks. 
medRxiv preprint doi: https://doi.org/10.1101/2022.02.17.22270256; this version posted February 19, 2022. The copyright holder for this preprint (which was not certified by peer review) is the author/funder, who has granted medRxiv a license to display the preprint in All rights reserved. No reuse allowed without permission.

\section{Group randomization, auditory stimulus and pairing procedure}

The random assignment of each participant to either the TMR or the control group took place at the end of the IRT session, before the last 5 minutes of imagery rehearsal. Patients were randomly assigned to one of the two experimental groups in randomization groups of six. Sampling was done without replacement, using the "Mersenne twister" algorithm for random number generation by Matsumoto and Nishimura (42). The final sequence was stored in a data table and used by the investigators for the allocation to incoming participants. The sequence was concealed from the participants so that they did not know which condition they were assigned to. Participants of the TMR group received a 1-sec sound (i.e., the neutral piano chord (69) every 10 seconds through headphones while they were imagining the new positive dream scenario of IRT for 5 minutes. To avoid extinction of the sound-dream association, the patients of this group were also asked to listen to the sound every day at home while they were practicing IRT. During the two weeks following Visit 2, all participants from the TMR and the control groups received the sound every 10 seconds during REM sleep (see 'Sleep assessment'). Before the patients returned home, and as individuals differ in their arousal threshold during sleep, the sound volume was calibrated for each participant individually (e.g. as in (34)).

\section{Sleep assessment}

Data from the actigraph and the sleep diary were collected from all participants for two weeks between Visit 1 and Visit 2. We could thus assess subjective sleep quality (from the diary) and sleep efficiency ( $\mathrm{SE}_{\text {Acti }}$ ) (from the actigraph). 
medRxiv preprint doi: https://doi.org/10.1101/2022.02.17.22270256; this version posted February 19, 2022. The copyright holder for this preprint (which was not certified by peer review) is the author/funder, who has granted medRxiv a license to display the preprint in

All rights reserved. No reuse allowed without permission.

A wearable sleep headband device Dreem ${ }^{\circledR}$ was then used to record sleep between Visit 2 and 3. Dreem ${ }^{\circledast}$ (Dreem SAS, Paris, https://dreem.com/en/product) is a wearable sleep headband and mobile application that monitors sleep by processing the EEG signal acquired from 4 frontal and 2 occipital locations in real-time. Dreem has been previously used to apply sounds during SWS (43) and can reliably detect different sleep stages through an automatic algorithm (44). For the purpose of the present project and in collaboration with the engineers from the company, we adapted the headband to apply sounds during REM sleep. Whenever REM sleep was detected for more than five minutes, the sound was delivered to the participants every 10 seconds. These stimulations were interrupted whenever a new sleep stage was detected (they restarted as soon as 5 minutes of stable REM were detected again), after detection of a movement (90 seconds of interruption), after detection of an alpha wave (45 seconds of interruption), after detection of a blink (10 seconds of interruption), or after bad quality signal (4 seconds of interruption). In the current protocol, the stimulation was applied at home in all participants for two weeks, between Visit 2 and Visit 3. This device also possesses an accelerometer and pulse oximeter. Its use for the two weeks of stimulation at home allowed us to calculate the number of stimulations, sound intensity, sleep efficiency (SEDreem), and a REM arousal index, defined here as the number of arousals in stage REM $\times 60 /$ REM duration in minutes.

\section{Dream Diary}

A dream diary was given to all participants for two weeks before Visit 2 and two weeks after. This dream diary was completed every morning upon awakening and helped us detect any potential differences in emotional dream content before and after the IRT, and between 
medRxiv preprint doi: https://doi.org/10.1101/2022.02.17.22270256; this version posted February 19, 2022. The copyright holder for this preprint (which was not certified by peer review) is the author/funder, who has granted medRxiv a license to display the preprint in All rights reserved. No reuse allowed without permission.

groups. It contained dichotomous questions (absence/presence) for specific emotions, including fear and joy, and offered the possibility to provide an open description of the dreams (see our previous study (45)). Based on our hypothesis that positive emotions should be reactivated by the TMR procedure, we focused our analyses on the dichotomous question about joy in the questionnaire, and its negative counterpart, fear, which may also be relevant for nightmare sufferers. We calculated (separately for each emotion) the proportion of dreams containing the emotion in the week preceding IRT (without sound stimulations) and during the week following IRT (with stimulations). To do so, we took the number of dreams where each of these emotions was present divided by the number of nights for which participants indicated that they experienced dreaming. This resulted in one proportion for each of these two emotions for the period before IRT and similarly for the week after IRT, and this for participants in the TMR and in the control groups.

\section{Questionnaires used during clinical assessments}

Clinical assessment of nightmare disorder was conducted at three time points (T1, T2, T3; Figure 1). We used the validated Nightmare Frequency Questionnaire (NFQ) (38), which retrospectively determines the frequency of nightmares per week and of nights with nightmares per week, and the validated Nightmare Distress Questionnaire (NDQ) (46), which evaluates the emotional disturbance attributed to the nightmares via 13 items scored on a scale ranging between "never" (0) and "always". In addition to NFQ and NDQ, we also assessed the sleep quality and mood of our patients at time points T1-T3 via the 19-item self-rated Pittsburgh Sleep Quality Index (PSQI) (40) and the 21-item self-rated Beck Depression Inventory II (BDI-II) (39), respectively. All four questionnaires have been widely used in the past to measure the efficacy of IRT $(47,48)$. 
medRxiv preprint doi: https://doi.org/10.1101/2022.02.17.22270256; this version posted February 19, 2022. The copyright holder for this preprint (which was not certified by peer review) is the author/funder, who has granted medRxiv a license to display the preprint in All rights reserved. No reuse allowed without permission.

\section{Primary and secondary outcome variables}

The total number of nightmares per week, as assessed by NFQ, was used as the primary outcome variable at T2 and T3, while the proportions of joy and fear in dreams were used as secondary outcome variables (see Introduction section) at T2. Other exploratory variables included the scores in NDQ, PSQI, BDI-Il questionnaires, sleep efficiency (SE).

\section{Statistical analyses}

We first checked whether the randomization successfully generated two equivalent groups of patients in terms of their general demographic and clinical characteristics. We compared the two groups using independent t-tests for continuous variables (baseline NFQ, NDQ, PSQI, BDI scores, age, $\left.\mathrm{SE}_{\mathrm{Acti}}\right)$. Independent t-tests between the two groups were also performed to check that patients from each group had similar stimulation conditions during the two weeks of stimulation at home (number of stimulations, sound intensity, $\mathrm{SE}_{\text {Dreem, }} \mathrm{REM}$ arousal index). When normal distribution was not respected (Shapiro-Wilk test $p<.05$ ), Mann-Whitney U tests between the two groups were conducted.

Next, to study the effects of TMR on the outcome variables, data were entered into a multilevel regression model, with the outcome variables as dependent variables, and Time $(\mathrm{T} 1, \mathrm{~T} 2, \mathrm{~T} 3)$ and Group (TMR group, control group) as (interacting) independent variables. The latter represented the fixed effects of the multilevel model, while the random effects were represented by a random intercept for subjects. The random intercept accounted for correlation between repeated measures, by assuming baseline differences between subjects 
medRxiv preprint doi: https://doi.org/10.1101/2022.02.17.22270256; this version posted February 19, 2022. The copyright holder for this preprint (which was not certified by peer review) is the author/funder, who has granted medRxiv a license to display the preprint in All rights reserved. No reuse allowed without permission.

in the average dependent variable. A multilevel regression was chosen for these data, due to its ability to handle (a) missing data in the time variable (due to the longitudinal dropout of the current study), (b) time-varying covariates, and (c) continuous within-subject covariates.

Once the model was fitted, we performed a Type II ANOVA breakdown of fixed effects using F-tests, starting with the interaction test of Time $\times$ Group, followed by main effects tests for Time and Group separately. Significant effects were further explored with pairwise $t$-tests. Degrees of freedom for all $F$ - and $t$-tests were adjusted for the random effects structure using Satterthwaite's method (49), yielding fractional degrees of freedom. Multilevel analyses were conducted with SPSS, version 23 (IBM Corp. Released 2015), using the MIXED procedure.

Bonferroni correction for multiple tests of the two emotions in dreams (i.e., joy, fear) were applied (significance level $\alpha=.05 / 2=.025)$.

\section{Results}

Recruitment took place from May 2020 to October 2021, with final follow-up data collected on January 2022. Figure S1 provides a CONSORT diagram of study participants (Supplementary Material).

\section{Baseline demographic, sleep and dream characteristics}

At T1, no significant baseline differences were found between the groups for demographic and clinical characteristics, including primary and secondary outcome variables (Table 1). 
medRxiv preprint doi: https://doi.org/10.1101/2022.02.17.22270256; this version posted February 19, 2022. The copyright holder for this preprint (which was not certified by peer review) is the author/funder, who has granted medRxiv a license to display the preprint in All rights reserved. No reuse allowed without permission.

\section{Sound stimulation at home}

No significant differences between the groups were observed for the average number of stimulations, average sound intensity, sleep efficiency ( $\mathrm{SE}_{\text {Dreem }}$ ) and REM arousal index (number of arousals in stage REM $\times 60 /$ REM duration) during the two weeks of IRT and stimulations, as measured by the sleep headband (Table 2).

-Please insert Table 2 here-

\section{Clinical outcome variables}

\section{Primary outcome variable}

There was a significant Time*Group interaction $(p=.006, F=5.81)$ and a significant effect of Time $(p=<.001, F=62.50)$ for NFQ (Figure 2). A pairwise t-test indicated that the TMR group had significantly lower NFQ score than the control group at T2 ( $p=.026, \mathrm{t}=-2.31$, Cohen's $\mathrm{d}=$ 1.05) and T3 ( $p=.006, \mathrm{t}=-2.87$, Cohen's $\mathrm{d}=1.45)$ (Table 3).

\section{Secondary outcome variables}

There was a significant Time*Group interaction $(p=.001, F=13.75)$ and a significant effect of Time $(p=<.001, F=25.98)$ for the emotion of joy in dreams (Figure 2). Pairwise t-tests indicated that the TMR group had significantly higher proportion of joy than the control group at T2 ( $p$ $=.004, \mathrm{t}=2.98$, Cohen's $\mathrm{d}=1.06)$, and that only the TMR group had higher joy in dreams in T2 compared to $T 1 \quad(p=<.001, t=6.14)$ (Table 3$)$. There was a significant effect of Time for the proportion of fear $(p=<.001, F=16.64)$, but no Group effect or Time*Group interaction. All other exploratory variables also displayed an effect of Time (NDQ: $p=<.001, F=22.25$; PSQI: 
medRxiv preprint doi: $h t t p s: / / d o i . o r g / 10.1101 / 2022.02 .17 .22270256$; this version posted February 19, 2022. The copyright holder for this preprint (which was not certified by peer review) is the author/funder, who has granted medRxiv a license to display the preprint in All rights reserved. No reuse allowed without permission.

$\mathrm{p}=<.001, \mathrm{~F}=11.73 ; \mathrm{BDI}-\mathrm{II}: \mathrm{p}=.003, \mathrm{~F}=6.32 ; \mathrm{SE}: \mathrm{p}=.006, \mathrm{~F}=8.59$ ), and no Group effect or Time*Group interaction (Table 3).

-Please insert Table 3 here-

\section{Effect of stimulations on REM sleep}

When comparing the first two nights of stimulations with the last two nights for the REM arousal index, there was no significant Time*Group interaction $(p=.851, F=.036)$, no effect of Time $(p=.929, F=008)$ or Group $(p=.221, F=1.56)$, meaning that stimulation (associated or not) did not alter REM sleep structure.

\section{Discussion}

We here show enhanced clinical improvement of the nightmare frequency in a population of nightmare sufferers under combined IRT and TMR compared to patients under IRT alone. Moreover, we report an increase in dreams containing positive emotions (i.e., joy) in the TMR group only. Together, these findings suggest that TMR during REM sleep may improve IRT outcome by favoring the activation of emotionally positive dreams, while almost totally suppressing nightmares.

We first show that IRT was effective for patients from both the TMR and control groups, with a significant effect of time across all variables (nightmare frequency, joy and fear in dreams, distress, mood scores, sleep quality). These results confirm previous reports showing that IRT 
medRxiv preprint doi: https://doi.org/10.1101/2022.02.17.22270256; this version posted February 19, 2022. The copyright holder for this preprint (which was not certified by peer review) is the author/funder, who has granted medRxiv a license to display the preprint in All rights reserved. No reuse allowed without permission.

reduces nightmare frequency and distress $(47,48)$, negative emotions in dreams $(50)$, while improving sleep quality $(47,51)$, insomnia severity $(52)$, mood scores $(47,53)$, and PTSD severity $(47,48)$. However, although IRT is the established treatment of nightmares since more than 30 years now (15), the lack of a control group (without IRT) in the current study design cannot exclude that the clinical improvements observed in both patients groups was influenced by other factors (e.g., patient expectations).

Critically, the frequency of weekly nightmares was further reduced in the TMR compared to the control group, thus supporting our hypothesis that TMR is an efficient method to potentialize IRT. This difference displayed a large effect size and was sustainable at the 3month follow-up, even without any intervention between the end of treatment (Visit 3) and the last assessment (Visit 4). The role of TMR in the consolidation of positive associative memories during REM sleep $(22,34)$, reflected by the significant increase of positive emotions (i.e., joy) in dreams of the TMR group, may provide a plausible mechanistic explanation for the therapeutic benefit of TMR in this study. As TMR did not further reduce nightmare distress or fear in dreams, the contributions of IRT and TMR to alleviating nightmares in this specific study may be partly dissociated, with IRT mostly inhibiting fear in dreams (e.g., fear extinction, rendering threatening stimuli more neutral), while TMR boosting emotionally positive dreams, as we further discuss below.

On the one hand, some authors also proposed that IRT may increase the feeling of mastery over dream content $(50,54)$. Indeed, the increase of control over the content of nightmares through mental imagery has been described as an important component of the IRT program (13). On the other hand, IRT may also directly affect emotion regulation systems (e.g., 
medRxiv preprint doi: https://doi.org/10.1101/2022.02.17.22270256; this version posted February 19, 2022. The copyright holder for this preprint (which was not certified by peer review) is the author/funder, who has granted medRxiv a license to display the preprint in All rights reserved. No reuse allowed without permission.

extinction learning) (55), a mechanism that is compatible with theoretical models of dreams and nightmares $(6,56)$. Indeed, dreams serve a fear extinction function by exposing the individual to feared stimuli (conditioned stimuli-CS) in a safe and virtual environment that does not predict the unconditioned stimulus-US (6). This procedure (CS-noUS associations and violation of expectancy) is the milestone of extinction and inhibitory learning (7). In a recent paper of our group (45), we showed that the more fear healthy participants had in their dreams, the less intense their fear response was while awake (i.e., decreased activity of amygdala and insula, paralleled by an increased activity of mPFC, when exposed to negative stimuli in the MRI scanner). This is consistent with extinction models according to which the mPFC exerts an inhibitory control over fear expression by reducing amygdala activity (9). Although the aforementioned emotional function of dreams applies to negative but somewhat benign dreams, it may be disrupted in the case of distressing nightmares. Indeed, some preliminary studies showed that nightmare patients demonstrate a decreased mPFC activity during the viewing of negative pictures (57). Therefore, rescripting a nightmare with a positive scenario, as in IRT, would represent a mental rehearsal of CS-noUS associations (7), with the concurrent presence of a feared stimulus and a tolerable outcome. IRT would then share similar mechanisms with exposure therapy $(53,58)$ by enhancing extinction and rendering threatening stimuli more neutral.

IRT with TMR during REM sleep in our protocol decreased the frequency of nightmares and increased positive emotions in dreams but did not further decrease fear in dreams compared to controls with IRT only. This suggests that positive dreams progressively took over nightmares as the most prevalent type of dreams in the patients of the TMR group. Recent studies demonstrated that TMR during REM sleep helps consolidate emotional associative 
medRxiv preprint doi: https://doi.org/10.1101/2022.02.17.22270256; this version posted February 19, 2022. The copyright holder for this preprint (which was not certified by peer review) is the author/funder, who has granted medRxiv a license to display the preprint in All rights reserved. No reuse allowed without permission.

memories (34) and increases positive valence of initially negative stimuli (22). Associating a positive scenario (during IRT) with a sound, as we did here, and replaying this association during REM sleep with TMR would then promote the long-term consolidation of this specific positive memory trace. This interpretation is also supported by the sustained effect observed after 3 months. Concurring with scarce previous research $(25,26)$, this study provides experimental evidence for a role of REM in the consolidation of positive associative memories.

There are certain limitations in this study. First, the current design lacked a group of nightmare patients without any stimulations. As mentioned above, the goal of the study was not to demonstrate the efficacy of the IRT itself, which is already well established for ND, but to test for any additive effect of TMR. Yet, because we did not acquire polysomnographic measures before stimulations, the current design does not allow assessing other possible unspecific effects of the sound stimulation on sleep. Another important aspect concerns the dropout rate at the 3-month follow-up evaluation (22\%), which is at the superior limits of general acceptability for long-term randomized trials (20\%) (59), although such a rate is expected in this specific group of clinical population (47). Please note, however, that this rate is lower than most studies using psychological treatments for nightmares, where the dropout rates range from $23 \%$ to $52 \%(60)$.

The present study establishes that associating TMR to IRT reduces nightmares frequency and fosters positive emotion in dreams. Such a TMR manipulation could accelerate a process whereby dreams regain their functional role of fear extinction. Thus, we propose that TMR in REM sleep could be used as a new 'sleep therapy' in other psychiatric disorders with deficient extinction/emotion regulation as well (e.g., anxiety disorders, PTSD, mood disorders, insomnia 
medRxiv preprint doi: https://doi.org/10.1101/2022.02.17.22270256; this version posted February 19, 2022. The copyright holder for this preprint (which was not certified by peer review) is the author/funder, who has granted medRxiv a license to display the preprint in

All rights reserved. No reuse allowed without permission.

disorder) $(61,62)$. By deploying and popularizing easy-to-use devices at home to produce permanent consolidation of safety memories, these therapies can easily reach the general population and lead to new innovative approaches for promoting emotional well-being.

Acknowledgments: The authors would like to thank Eleni Thomas, Ben Meuleman, Francesca Borghese, Pauline Henckaerts, Guillaume Legendre, Stephen Perrig, Virginie Sterpenich, Laurence Bayer and Kinga Igloi for useful discussions regarding this manuscript. This manuscript has been submitted to medRxiv. This study was supported by Swiss National Science Foundation, Grant/Award Number: CRSK-3_190722.

Disclosures: The authors report no potential conflicts of interest. 
medRxiv preprint doi: https://doi.org/10.1101/2022.02.17.22270256; this version posted February 19, 2022. The copyright holder for this preprint (which was not certified by peer review) is the author/funder, who has granted medRxiv a license to display the preprint in All rights reserved. No reuse allowed without permission.

\section{References}

1. Robert G, Zadra A (2014): Thematic and content analysis of idiopathic nightmares and bad dreams. Sleep. 37:409-417.

2. American Psychiatric Association (2013): Diagnostic and Statistical Manual of Mental Disorders, 5th edn. Arlington, VA: American Psychiatric Publishing.

3. American Academy of Sleep Medicine (2014): ICSD-3-International classification of sleep disorders. 3d ed ed. Illinois: Darien: American Academy of Sleep Medicine.

4. Munezawa T, Kaneita Y, Osaki Y, Kanda H, Ohtsu T, Suzuki H, et al. (2011): Nightmare and sleep paralysis among Japanese adolescents: a nationwide representative survey. Sleep Med. 12:56-64.

5. Sandman N, Valli K, Kronholm E, Ollila HM, Revonsuo A, Laatikainen T, et al. (2013): Nightmares: Prevalence among the Finnish General Adult Population and War Veterans during 1972-2007. Sleep. 36:1041-1050.

6. Nielsen T, Levin R (2007): Nightmares: a new neurocognitive model. Sleep Med Rev. 11:295-310.

7. Craske MG, Hermans D, Vervliet B (2018): State-of-the-art and future directions for extinction as a translational model for fear and anxiety. Philos Trans $R$ Soc Lond B Biol Sci. 373.

8. Krabbe S, Grundemann J, Luthi A (2018): Amygdala Inhibitory Circuits Regulate Associative Fear Conditioning. Biol Psychiatry. 83:800-809.

9. Phelps EA, Delgado MR, Nearing KI, LeDoux JE (2004): Extinction learning in humans: role of the amygdala and vmPFC. Neuron. 43:897-905.

10. Milad MR, Wright Cl, Orr SP, Pitman RK, Quirk GJ, Rauch SL (2007): Recall of fear extinction in humans activates the ventromedial prefrontal cortex and hippocampus in concert. Biol Psychiatry. 62:446-454.

11. Schreuder BJ, Kleijn WC, Rooijmans HG (2000): Nocturnal re-experiencing more than forty years after war trauma. J Trauma Stress. 13:453-463.

12. Aurora RN, Zak RS, Auerbach SH, Casey KR, Chowdhuri S, Karippot A, et al. (2010): Best practice guide for the treatment of nightmare disorder in adults. J Clin Sleep Med. 6:389401.

13. Krakow B, Zadra A (2010): Imagery Rehearsal Therapy: Principles and Practice. Sleep Medicine Clinics. 5:289-298.

14. Neidhardt EJ, Krakow B, Kellner R, Pathak D (1992): The beneficial effects of one treatment session and recording of nightmares on chronic nightmare sufferers. Sleep. 15:470-473.

15. Kellner R, Neidhardt J, Krakow B, Pathak D (1992): Changes in chronic nightmares after one session of desensitization or rehearsal instructions. Am J Psychiatry. 149:659-663.

16. Germain A, Nielsen T (2003): Impact of imagery rehearsal treatment on distressing dreams, psychological distress, and sleep parameters in nightmare patients. Behav Sleep Med. 1:140-154.

17. Menz MM, Rihm JS, Buchel C (2016): REM Sleep Is Causal to Successful Consolidation of Dangerous and Safety Stimuli and Reduces Return of Fear after Extinction. J Neurosci. 36:2148-2160.

18. Pace-Schott EF, Germain A, Milad MR (2015): Effects of sleep on memory for conditioned fear and fear extinction. Psychol Bull. 141:835-857. 
medRxiv preprint doi: https://doi.org/10.1101/2022.02.17.22270256; this version posted February 19, 2022. The copyright holder for this preprint (which was not certified by peer review) is the author/funder, who has granted medRxiv a license to display the preprint in All rights reserved. No reuse allowed without permission.

19. Bottary R, Seo J, Daffre C, Gazecki S, Moore KN, Kopotiyenko K, et al. (2020): Fear extinction memory is negatively associated with REM sleep in insomnia disorder. Sleep. 43.

20. Marshall AJ, Acheson DT, Risbrough VB, Straus LD, Drummond SP (2014): Fear conditioning, safety learning, and sleep in humans. J Neurosci. 34:11754-11760.

21. Spoormaker VI, Schroter MS, Andrade KC, Dresler M, Kiem SA, Goya-Maldonado R, et al. (2012): Effects of rapid eye movement sleep deprivation on fear extinction recall and prediction error signaling. Hum Brain Mapp. 33:2362-2376.

22. Rihm JS, Rasch B (2015): Replay of conditioned stimuli during late REM and stage N2 sleep influences affective tone rather than emotional memory strength. Neurobiol Learn Mem. 122:142-151.

23. Gujar N, McDonald SA, Nishida M, Walker MP (2011): A role for REM sleep in recalibrating the sensitivity of the human brain to specific emotions. Cereb Cortex. 21:115-123.

24. van der Helm E, Yao J, Dutt S, Rao V, Saletin JM, Walker MP (2011): REM sleep depotentiates amygdala activity to previous emotional experiences. Curr Biol. 21:20292032.

25. Chambers A, Payne J (2014): The Influence of Sleep on the Consolidation of Positive Emotional Memories: Preliminary Evidence. AIMS Neuroscience. 1:39-51.

26. Carr M, Nielsen T (2015): Morning rapid eye movement sleep naps facilitate broad access to emotional semantic networks. Sleep. 38:433-443.

27. Oudiette D, Paller KA (2013): Upgrading the sleeping brain with targeted memory reactivation. Trends Cogn Sci. 17:142-149.

28. Rasch B, Buchel C, Gais S, Born J (2007): Odor cues during slow-wave sleep prompt declarative memory consolidation. Science. 315:1426-1429.

29. Antony JW, Gobel EW, O'Hare JK, Reber PJ, Paller KA (2012): Cued memory reactivation during sleep influences skill learning. Nat Neurosci. 15:1114-1116.

30. Diekelmann S (2014): Sleep for cognitive enhancement. Front Syst Neurosci. 8:46.

31. Rasch B (2018): Let's replay. Elife. 7.

32. Smith C, Weeden K (1990): Post training REMs coincident auditory stimulation enhances memory in humans. Psychiatr J Univ Ott. 15:85-90.

33. Guerrien A, Dujardin K, Mandai O, Sockeel P, Leconte P (1989): Enhancement of memory by auditory stimulation during postlearning REM sleep in humans. Physiol Behav. 45:947950.

34. Sterpenich V, Schmidt C, Albouy G, Matarazzo L, Vanhaudenhuyse A, Boveroux P, et al. (2014): Memory reactivation during rapid eye movement sleep promotes its generalization and integration in cortical stores. Sleep. 37:1061-1075, 1075A-1075B.

35. Rihm JS, Sollberger SB, Soravia LM, Rasch B (2016): Re-presentation of Olfactory Exposure Therapy Success Cues during Non-Rapid Eye Movement Sleep did not Increase Therapy Outcome but Increased Sleep Spindles. Front Hum Neurosci. 10:340.

36. Walker MP, van der Helm E (2009): Overnight therapy? The role of sleep in emotional brain processing. Psychol Bull. 135:731-748.

37. Datta S, O'Malley MW (2013): Fear extinction memory consolidation requires potentiation of pontine-wave activity during REM sleep. J Neurosci. 33:4561-4569.

38. Krakow B, Schrader R, Tandberg D, Hollifield M, Koss MP, Yau CL, et al. (2002): Nightmare frequency in sexual assault survivors with PTSD. J Anxiety Disord. 16:175-190.

39. Beck AT, Steer RA, Ball R, Ranieri W (1996): Comparison of Beck Depression Inventories IA and -II in psychiatric outpatients. J Pers Assess. 67:588-597. 
medRxiv preprint doi: https://doi.org/10.1101/2022.02.17.22270256; this version posted February 19, 2022. The copyright holder for this preprint (which was not certified by peer review) is the author/funder, who has granted medRxiv a license to display the preprint in

All rights reserved. No reuse allowed without permission.

40. Buysse DJ, Reynolds CF, 3rd, Monk TH, Berman SR, Kupfer DJ (1989): The Pittsburgh Sleep Quality Index: a new instrument for psychiatric practice and research. Psychiatry Res. 28:193-213.

41. Simon K, Gomez RL, Nadel L (2018): Losing memories during sleep after targeted memory reactivation. Neurobiol Learn Mem. 151:10-17.

42. Matsumoto $M$, Nishimura $T$ (1998): Mersenne twister: a 623-dimensionally equidistributed uniform pseudo-random number generator. ACM Transactions on Modeling and Computer Simulation. 8:3-30.

43. Debellemaniere E, Chambon S, Pinaud C, Thorey V, Dehaene D, Leger D, et al. (2018): Performance of an Ambulatory Dry-EEG Device for Auditory Closed-Loop Stimulation of Sleep Slow Oscillations in the Home Environment. Front Hum Neurosci. 12:88.

44. Arnal PJ, Thorey V, Debellemaniere E, Ballard ME, Bou Hernandez A, Guillot A, et al. (2020): The Dreem Headband compared to polysomnography for electroencephalographic signal acquisition and sleep staging. Sleep. 43.

45. Sterpenich V, Perogamvros L, Tononi G, Schwartz S (2020): Fear in dreams and in wakefulness: Evidence for day/night affective homeostasis. Hum Brain Mapp. 41:840850.

46. Belicki K (1992): The relationship of nightmare frequency to nightmare suffering with implications for treatment and research. Dreaming. 2:143-148.

47. Krakow B, Hollifield M, Johnston L, Koss M, Schrader R, Warner TD, et al. (2001): Imagery rehearsal therapy for chronic nightmares in sexual assault survivors with posttraumatic stress disorder: a randomized controlled trial. JAMA. 286:537-545.

48. Hansen K, Hofling V, Kroner-Borowik T, Stangier U, Steil R (2013): Efficacy of psychological interventions aiming to reduce chronic nightmares: a meta-analysis. Clin Psychol Rev. 33:146-155.

49. Fitzmaurice GM, Laird NM, Ware JH (2004): Applied longitudinal analysis. Hoboken: John Wiley \& Sons.

50. Germain A, Krakow B, Faucher B, Zadra A, Nielsen T, Hollifield M, et al. (2004): Increased Mastery Elements Associated With Imagery Rehearsal Treatment for Nightmares in Sexual Assault Survivors With PTSD. . Dreaming. 14(4):195-206.

51. Casement MD, Swanson LM (2012): A meta-analysis of imagery rehearsal for post-trauma nightmares: effects on nightmare frequency, sleep quality, and posttraumatic stress. Clin Psychol Rev. 32:566-574.

52. Lancee J, Effting M, Kunze AE (2021): Telephone-guided imagery rehearsal therapy for nightmares: Efficacy and mediator of change. J Sleep Res. 30:e13123.

53. Lancee J, Spoormaker VI, van den Bout J (2010): Cognitive-behavioral self-help treatment for nightmares: a randomized controlled trial. Psychother Psychosom. 79:371-377.

54. Harb G, Brownlow J, Ross R (2016): Posttraumatic nightmares and imagery rehearsal: the possible role of lucid dreaming. . Dreaming. 26:238e249.

55. Rousseau A, Belleville G (2018): The mechanisms of action underlying the efficacy of psychological nightmare treatments: A systematic review and thematic analysis of discussed hypotheses. Sleep Med Rev. 39:122-133.

56. Revonsuo A (2000): The reinterpretation of dreams: an evolutionary hypothesis of the function of dreaming. Behav Brain Sci. 23:877-901; discussion 904-1121.

57. Marquis L, Blanchette-Carriere C, Carr M, Julien S, Paquette T, Nielsen T (2016): Decreased activity in medial prefrontal cortex and anterior cingulate cortex in idiopathic nightmare sufferers during wakefulness. Sleep 39:A226-227. 
medRxiv preprint doi: https://doi.org/10.1101/2022.02.17.22270256; this version posted February 19, 2022. The copyright holder for this preprint (which was not certified by peer review) is the author/funder, who has granted medRxiv a license to display the preprint in All rights reserved. No reuse allowed without permission.

58. Kunze AE, Arntz A, Morina N, Kindt M, Lancee J (2017): Efficacy of imagery rescripting and imaginal exposure for nightmares: A randomized wait-list controlled trial. Behav Res Ther. 97:14-25.

59. Fewtrell MS, Kennedy K, Singhal A, Martin RM, Ness A, Hadders-Algra M, et al. (2008): How much loss to follow-up is acceptable in long-term randomised trials and prospective studies? Arch Dis Child. 93:458-461.

60. Augedal AW, Hansen KS, Kronhaug CR, Harvey AG, Pallesen S (2013): Randomized controlled trials of psychological and pharmacological treatments for nightmares: a metaanalysis. Sleep Med Rev. 17:143-152.

61. Craske MG, Stein MB (2016): Anxiety. Lancet. 388:3048-3059.

62. Perogamvros L, Castelnovo A, Samson D, Dang-Vu TT (2020): Failure of fear extinction in insomnia: An evolutionary perspective. Sleep Med Rev. 51:101277. 
medRxiv preprint doi: https://doi.org/10.1101/2022.02.17.22270256; this version posted February 19, 2022. The copyright holder for this preprint (which was not certified by peer review) is the author/funder, who has granted medRxiv a license to display the preprint in All rights reserved. No reuse allowed without permission.

\section{Figure legends}

Figure 1. Design of the Experiment. Patients with ND had a first clinical assessment of nightmare intensity and frequency with standardized questionnaires at time Visit 1, after which they filled in a sleep and dream diary at home and wore an actigraph for two weeks. At the end of this period, they had an Imagery Rehearsal Therapy (IRT) session (Visit 2). At the end of this session, patients imagined the new positive ending of their nightmare either in the presence of a contextual sound (TMR group) or not (control group). For the following two weeks, all patients (TMR group, control group) were presented the sound during REM sleep at home with a headband device, while filling in a dream diary every morning. Nightmare intensity and frequency was measured again after two weeks of TMR at home (Visit 3), and 3 months later (Visit 4). Dream diaries were collected continuously between Visit 1 and Visit 3.

Figure 2. Treatment effects on (A) NFQ score (number of nightmares per week) and (B) proportion of joy in dreams. Data for the TMR and the control groups at baseline (T1), two weeks after IRT (T2) and at 3-month follow-up (T3). Error bars represent 95\% Cl. 
medRxiv preprint doi: https://doi.org/10.1101/2022.02.17.22270256; this version posted February 19, 2022. The copyright holder for this preprint (which was not certified by peer review) is the author/funder, who has granted medRxiv a license to display the preprint in

perpetuity.
All rights reserved. No reuse allowed without permission.

\section{Table legends}

Table 1. Baseline demographic, sleep and dream characteristics

Means, standard deviations and comparison between the control and TMR group, for age, female sex and outcome variables at T1.

Table 2. Comparison between groups during auditory stimulations

Means, standard deviations and comparison between the control and TMR group (Student $t$ test) of the average number of stimulations, average sound intensity, sleep efficiency (SEDreem) and REM arousal index (number of arousals in stage REM $\times 60 / R E M$ duration) during the two weeks of IRT as measured by the Dreem headband.

Table 3. Comparison between TMR and control group for the outcome variables at T2 and T3. 
medRxiv preprint doi: https://doi.org/10.1101/2022.02.17.22270256; this version posted February 19, 2022. The copyright holder for this preprint (which was not certified by peer review) is the author/funder, who has granted medRxiv a license to display the preprint in

All rights reserved. No reuse allowed without permission.

\section{Tables}

\section{Table 1}

\begin{tabular}{|c|c|c|c|c|c|c|}
\hline & $\begin{array}{l}\text { TMR group } \\
\qquad(\mathrm{N}=18)\end{array}$ & $\begin{array}{l}\text { Control group } \\
\qquad(\mathrm{N}=18)\end{array}$ & $d f$ & $\mathrm{t}$ & $p$-value & $d$ \\
\hline Age (years) & $26.11 \pm 3.67$ & $24.88 \pm 3.86$ & 34 & 1.16 & 0.25 & 0.32 \\
\hline Female sex & 13 & 14 & 1 & 0.14 & 0.70 & 0.06 \\
\hline $\mathrm{NFQ}_{\mathrm{T} 1}$ & $2.94 \pm 1.73$ & $2.58 \pm 1.19$ & 34 & 0.38 & 0.72 & 0.24 \\
\hline $\mathrm{BDI}-\mathrm{II}_{\mathrm{T} 1}$ & $14.55 \pm 7.72$ & $12.83 \pm 8.80$ & 34 & 0.82 & 0.42 & 0.20 \\
\hline $\mathrm{NDQ}_{\mathrm{T} 1}$ & $27.61 \pm 7.53$ & $26.55 \pm 7.65$ & 34 & 0.41 & 0.67 & 0.13 \\
\hline $\mathrm{PSQI}_{\mathrm{T} 1}$ & $7.77 \pm 2.86$ & $7.55 \pm 3.22$ & 34 & 0.22 & 0.82 & 0.07 \\
\hline$S E_{\text {Acti }}(\%)$ & $84.96 \pm 6.62$ & $88.00 \pm 8.61$ & 34 & -1.14 & 0.26 & 0.39 \\
\hline $\mathrm{JOY}_{\mathrm{T} 1}$ & $0.12 \pm 0.24$ & $0.17 \pm 0.18$ & 34 & -0.64 & 0.52 & 0.23 \\
\hline FEAR $_{T 1}$ & $0.57 \pm 0.33$ & $0.62 \pm 0.24$ & 34 & -0.55 & 0.58 & 0.17 \\
\hline \multicolumn{7}{|c|}{$\begin{array}{l}\text { Values are reported as mean } \pm S D \text {. For each variable, the degrees of freedom, Student's } t \text { value ( } X^{2} \text { for } \\
\text { female sex), the } p \text {-value and Cohen's } d \text { values (Cramér's V for female sex) are reported. NFQ: number }\end{array}$} \\
\hline \multicolumn{7}{|c|}{ of nightmares per week, BDI-II: Beck Depression Inventory, NDQ: Nightmare Distress Questionnaire, } \\
\hline \multicolumn{7}{|c|}{ PSQI: Pittsburgh Sleep Quality Index, SE: sleep efficiency, JOY ${ }_{T 1} /$ FEART1: proportion of dreams with joy } \\
\hline
\end{tabular}


medRxiv preprint doi: https://doi.org/10.1101/2022.02.17.22270256; this version posted February 19, 2022. The copyright holder for this preprint (which was not certified by peer review) is the author/funder, who has granted medRxiv a license to display the preprint in

All rights reserved. No reuse allowed without permission.

Table 2.

\begin{tabular}{|c|c|c|c|c|c|c|}
\hline & $\begin{array}{l}\text { TMR group } \\
\quad(\mathrm{N}=18)\end{array}$ & $\begin{array}{l}\text { Control group } \\
\qquad(\mathrm{N}=18)\end{array}$ & $d f$ & $\mathrm{t}$ & $p$-value & $d$ \\
\hline $\mathrm{Nb}$ of stimulations & $136.39 \pm 97.68$ & $160.88 \pm 67.59$ & 34 & -0.85 & 0.39 & 0.29 \\
\hline Sound intensity & $46.61 \pm 18.58$ & $38.88 \pm 22.06$ & 34 & 1.12 & 0.27 & 0.37 \\
\hline $\mathrm{SE}_{\text {Dreem }}(\%)$ & $89.01 \pm 5.77$ & $91.66 \pm 3.13$ & 34 & -1.14 & 0.25 & 0.57 \\
\hline REM arousal index & $3.63 \pm 1.89$ & $2.82 \pm 0.97$ & 34 & 1.33 & 0.18 & 0.53 \\
\hline
\end{tabular}

Table 3

\begin{tabular}{lcclcc}
\hline & $\begin{array}{c}\text { TMR group } \\
(\mathrm{N}=18)\end{array}$ & $\begin{array}{c}\text { Control group } \\
(\mathrm{N}=18)\end{array}$ & $\mathrm{p}$-value & T score & $\mathrm{d}$ \\
\hline $\mathrm{NFQ}_{\text {T2 }}$ & $0.19 \pm 0.38$ & $1.01 \pm 0.83$ & $\mathrm{p}=.026^{*}$ & -2.31 & 1.05 \\
$\mathrm{NFQ}_{\text {T3 }}$ & $0.33 \pm 0.56$ & $1.48 \pm 0.94$ & $\mathrm{p}=.006^{*}$ & -2.87 & 1.45 \\
JOY $_{\text {T2 }}$ & $0.46 \pm 0.27$ & $0.22 \pm 0.17$ & $\mathrm{p}=.004^{* *}$ & 2.98 & 1.06 \\
FEAR $_{\text {T2 }}$ & $0.36 \pm 0.27$ & $0.37 \pm 0.19$ & $\mathrm{p}=.97$ & -0.037 & 0.04 \\
NDQ $_{\text {T2 }}$ & $19.66 \pm 6.73$ & $20.22 \pm 8.25$ & $\mathrm{p}=.82$ & -0.22 & 0.07 \\
$\mathrm{NDQ}_{\text {T3 }}$ & $20.25 \pm 8.62$ & $22.50 \pm 7.10$ & $\mathrm{p}=.35$ & -0.92 & 0.28 \\
PSQI $_{\text {T2 }}$ & $6.22 \pm 2.60$ & $6.16 \pm 2.57$ & $\mathrm{p}=.95$ & 0.06 & 0.02 \\
$\mathrm{PSQI}_{\text {T3 }}$ & $5.08 \pm 1.31$ & $4.83 \pm 1.99$ & $\mathrm{p}=.55$ & 0.59 & 0.14 \\
BDI $_{\text {T2 }}$ & $11.00 \pm 8.17$ & $8.50 \pm 5.04$ & $\mathrm{p}=.32$ & 0.99 & 0.36 \\
BDI $_{\text {T3 }}$ & $10.83 \pm 9.04$ & $8.83 \pm 6.23$ & $\mathrm{p}=.72$ & 0.34 & 0.25
\end{tabular}


medRxiv preprint doi: https://doi.org/10.1101/2022.02.17.22270256; this version posted February 19, 2022. The copyright holder for this preprint (which was not certified by peer review) is the author/funder, who has granted medRxiv a license to display the preprint in perpetuity.

All rights reserved. No reuse allowed without permission.

Values are reported as mean \pm SD. NFQ: number of nightmares per week, BDI-II: Beck Depression Inventory, NDQ: Nightmare Distress Questionnaire, PSQI: Pittsburgh Sleep Quality Index, JOY T2/FEART2: proportion of dreams with joy and fear, respectively, among all remembered dreams during two weeks of IRT. Pairwise comparisons with Sidak correction. ${ }^{*} p<.05,{ }^{* *} p<.025$ (Bonferroni correction) 
medRxiv preprint doi: https://doi.org/10.1101/2022.02.17.22270256; this version posted February 19, 2022. The copyright holder for this preprint (which was not certified by peer review) is the author/funder, who has granted medRxiv a license to display the preprint in

All rights reserved. No reuse allowed without permission.

\section{Figures}

\section{Figure 1}

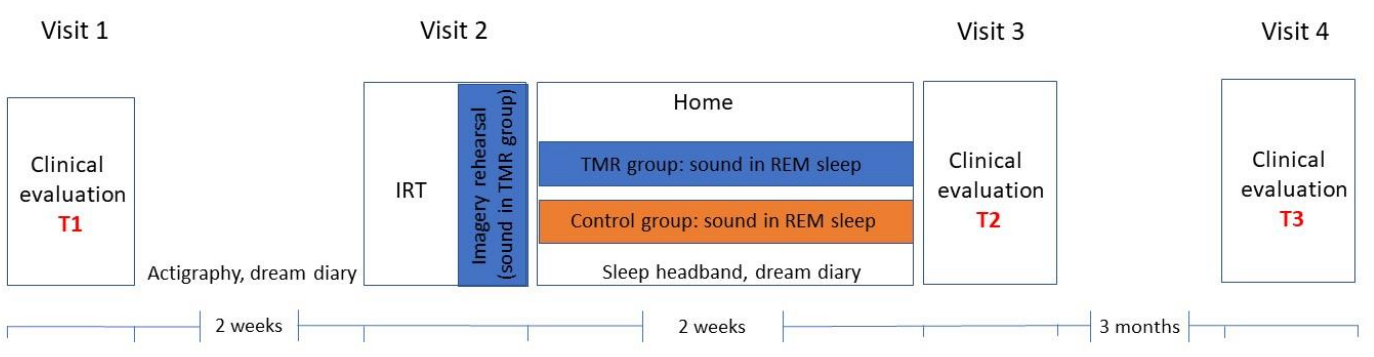

\section{Figure 2}

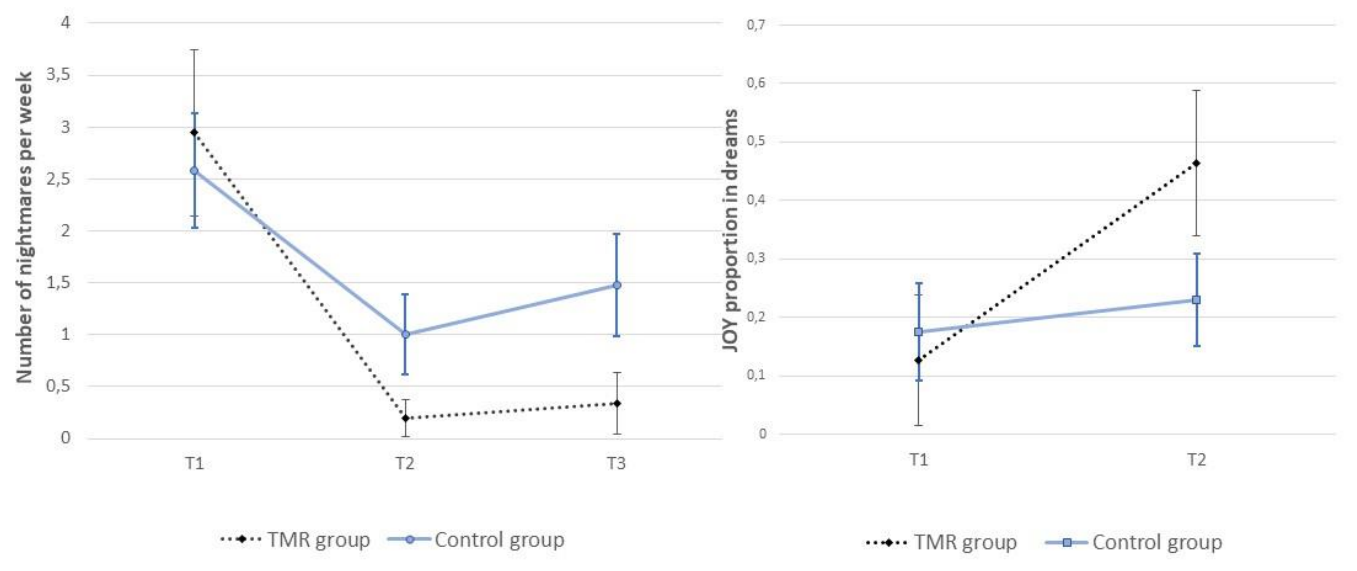

